\title{
Accounting
}

\section{Major shareholders and the effectiveness of the management's advising and monitoring functions: Empirical study}

\author{
Khaled Salmen Aljaaidi $^{\mathrm{a}^{*}}$ and Omar Ali Bagais ${ }^{\mathrm{a}}$
}

${ }^{a}$ Accounting Department, College of Business Administration. Prince Sattam bin Abdulaziz University, Saudi Arabia

\section{H R O N I C L E A B S T R A C T}

Article history:

Received: January 12, 2021

Received in revised format:

April 82021

Accepted: April 12, 2021

Available online:

April 14, 2021

Keywords:

Major family shareholder

Management's effectiveness

Saudi Arabia

\begin{abstract}
This study examines the connection of major family shareholders with management's effective attributes, namely; board size and board meetings as an interaction term among 464 manufacturing listed companies in the setting of Saudi Arabia for the period 2012-2019. The pooled OLS regression result indicated that the major family shareholders were associated negatively with management's effectiveness. The main result documented by this study is of utmost importance to policy makers, regulators, companies, and auditors in Saudi Arabia on understanding the extent to which the major shareholders influence the degree of management's effectiveness.
\end{abstract}

\section{Introduction}

A board of directors has an essential part to play in overseeing and guiding organizational operations (Raheja 2005; Adams and Ferreira 2007). The guidance role relates to organizational strategy, whilst the oversight role is more focused on overseeing an organization's every day operations. The primary aim of having a board of directors with oversight is to effect reductions in agency problems by making managers responsible for their decisions. How closely managers will be monitored and controlled is dependent upon how many directors there are (Jensen, 1993; Lipton \& Lorsch, 1992). Alongside their oversight and guidance roles, boards of directors are also central to exercising discipline and replacing weak management teams in order to make sure that managers remain proactive and work hard for shareholders (Guest, 2009). Jensen (1993) noted that boards of directors with many members tend to overshadow management teams and it is hard to achieve unanimity regarding important decisions, which in turn means less safeguarding of shareholder interests. Goodstein et al. (1994) concur with this perspective, stating that governing boards with between four and six directors have greater effectiveness than more substantial ones as they are able to achieve consensus more quickly. The guidance role of a board of directors is to assist management with strategies for creating value for the company (Coles et al., 2008). The board of directors also offers the CEO the benefit of their expertise and brings in crucial resources and information (Fama \& Jensen, 1983). Pearce and Zahra (1992) suggest that a substantial board of directors can control organizations. They contend that larger boards of directors are preferable for control purposes because they are not as easily dominated by management and they can incorporate a variety of individuals of different intellectual and knowledge levels who will be able to identify and combat managers who become too dominant in order to protect shareholder

* Corresponding author

E-mail address: k.aljaaidi@psau.edu.sa (K. S. Aljaaidi)

(C) 2021 by the authors; licensee Growing Science, Canada doi: $10.5267 /$ j.ac.2021.4.015 
interests. Larger boards of directors are also beneficial as they can bring in larger amounts of information. Chaganti, Mahajan, and Sharma (1985) also state that larger board of directors bring a wider variety of services to their role. It is regarded as crucial for both guidance and oversight that a board of directors should meet frequently. Board meetings play an essential part in coordination between board members and undertaking their tasks efficiently. Additionally, board meetings provide a useful working environment and provide directors with guidance that will help them be effective in overseeing managers. If directors frequently miss meetings, this may lead to a reduction in the quality of monitoring (Lipton \& Lorsch, 1992; Baccouche et al., 2014; Jiraporn et al., 2009; Conger et al., 1998; Vafeas, 1999; Brick \& Chidambaran, 2010; Ramos \& Olalla, 2011; Agrawal \& Knoeber, 2001; Agrawal \& Knoeber, 2001). Carcello et al. (2002) state that board meetings make a board's supervisory role more effective. Vafeas (1999) agrees, stating that boards become more effective and better managers when they meet regularly, and they will also be able to access essential information to help them do this. Adams and Ferrera (2007, 2011) suggests that a board that is diligent in carrying out the oversight role has a greater likelihood of carrying out successful monitoring of financial reports. Yatim et al (2006) state that researchers currently perceive board meeting frequency as being and alternative measure of success that can replace observations of service delivery levels (Greco, 2010; Vafeas, 1999; Laksmana, 2008). Several prior studies examined the board meeting frequency with different issues in several developed and developing countries (Aljaaidi et al., 2021; Bagais \& Aljaaidi, 2020; Greco, 2010; Vafeas, 1999; Hahn, 2007; Baccouche et al., 2014; Hahn \& Lasfer, 2016; Lin et al., 2014), ignoring the impact of major family shareholders. In this regard, the study of Greco (2010) examined the associations of concertation ownership and insider ownership with board meetings. He found a negative relationship between the insider ownership and the frequency of board meetings. Furthermore, Al-Janadi et al. (2016) examined the moderating effect of government ownership on the association between corporate governance and voluntary disclosure. They found that government ownership has a moderating negative effect on the association between corporate governance factors, namely; board size and non-executive directors, and voluntary disclosure, indicating a negative role of government ownership in the effectiveness of corporate governance. The empirical setting of our study is Saudi Arabia which is characterized to have a domination by major shareholders such as families (Chahine, 2007; Chahine \& Tohme, 2009; Omran et al., 2008). Additionally, the study utilizes a composite measure of the board of directors' effectiveness, including the board size and board meetings. The result shows that the measurement of the combined impact indicates a stronger effect than the measurement of individual impacts (Cai et al., 2009; Ward et al., 2009; Agrawal \& Knoeber, 1996; O’Sullivan et al., 2008). Saudi Arabia has experienced tremendous reforms in corporate governance in recent times. The reforms began in 2000 when the attention was focused on the internal control system coupled with the Saudi Code of Corporate Governance issuance in 2006 (Al-Thuneibat et al., 2015; Alzahrani, 2013; Barako et al., 2006). The 2006 Code is based on the Capital Market Law issued by Royal Decree No. M/30 dated January 1, 1996, that is amended by Resolution of the Board of the Capital Market Authority Number 1-10-2010 dated March 16, 2010. The Code has helped strengthen Saudi Arabia's corporate governance (Corporate Governance Regulations in the Kingdom of Saudi Arabia, 2006). In specific, The Saudi Code of Corporate Governance (SCGC) focuses on the composition of the board. In Article 12, the code recommends that the size of the board should be not less than three and not more than eleven members. As for the board meetings, the SCGC has not specified a certain number of meetings in the year. It asserts that board members shall perform their duties, carry out their responsibilities and endeavor to attend all meetings (Article 16). Furthermore, the board shall hold ordinary meetings regularly. Also, the board shall document its meetings and prepare records of the deliberations and voting.

This study examines the relationship between the major family shareholders and the board of directors' effectiveness, namely; board size and board meetings as a composite score in the setting of Saudi stock market. Overall, this study contributes to the body of knowledge in several ways. First, to the best of our knowledge, this study is the first to examine several classifications of major family shareholders with board of directors' composite score, namely; board size and meetings. Our contribution to the previous literature provides evidence showing the negative impact of the several classifications of major family shareholders on the board of directors' effectiveness. We believe that our study provides a broad and important contribution to literature of ownership structure and board of directors' effectiveness in the context of Saudi Arabia. In addition, this study uses the agency theory framework to explain the relationship between the ownership structure and board of directors' effectiveness.

The paper proceeds as follows: Section 2 provides a review of the literature and hypotheses development. Section 3 describes the research design and methodology. Section 4 highlights the empirical results and discussions. Section 5 provides the conclusions and implications.

\section{Research Design and Methodology}

\subsection{Sample and Data}

The sample of this study consists of manufacturing companies listed on Saudi Stock Exchange for the period ranging from 2012 to 2019 that disclose corporate governance and financial information. The data was collected by hand from the financial statements. The final sample is depicted in the following Table 1: 
Table 1

Sample size

\begin{tabular}{lc}
\hline & Totals \\
\hline Total listed companies & 58 firms \\
Number of years observed & 8 years \\
Total observation & 464 \\
\hline Final sample & 464 \\
\hline
\end{tabular}

\subsection{Model Specification}

Pooled Ordinary least square model OLS was specified to examine the association of board of directors' effectiveness $B D E F F$, namely; board size BDSIZE and meetings BDMEET, with major family shareholders MAJFSHARE, firm size FSIZE, firm leverage $L E V$ and firm performance $R O A$. The functional equation of the pooled OLS regression model is utilized to determine the extent of the association of each of the independent variables on the $B D E F F$.

$$
\mathrm{BDEFF}=\beta 0+\beta_{1} \mathrm{MAJFSHARE}+\beta_{2} \mathrm{FSIZE}+\beta_{3} \mathrm{LEV}+\beta_{4} \mathrm{ROA}+\mathrm{e}
$$

where:

\begin{tabular}{|c|c|c|}
\hline BDEFF & $=$ & Interaction term of board size and board meetings \\
\hline \multirow[t]{7}{*}{ MAJFSHARE } & $=$ & $1=$ if the firm has a major family shareholders owning $5 \%$ and above, $0=$ otherwise \\
\hline & $=$ & $1=$ if the firm has a major family shareholders owning $10 \%$ and above, $0=$ otherwise \\
\hline & $=$ & $1=$ if the major family shareholders own $(10-20 \%)$ of the shares, $0=$ otherwise \\
\hline & $=$ & $1=$ if the major family shareholders own $(21-30 \%)$ of the shares, $0=$ otherwise \\
\hline & $=$ & $1=$ if the major family shareholders own $(31-40 \%)$ of the shares, $0=$ otherwise \\
\hline & $=$ & $1=$ if the major family shareholders own $(41-50 \%)$ of the shares, $0=$ otherwise \\
\hline & $=$ & $1=$ if the major family shareholders own $(>51 \%)$ of the shares, $0=$ otherwise \\
\hline FSIZE & $=$ & $\log _{10}$ of total assets \\
\hline LEV & $=$ & Debt to total assets ratio \\
\hline $\mathrm{ROA}$ & $=$ & Return on assets \\
\hline $\mathrm{e}$ & $=$ & error term. \\
\hline
\end{tabular}

Several control variables have been included in the model of this study. Firm size FSIZE is expected to have a positive relationship with the board of directors' effectiveness BDEFF (Greco, 2010; Hahn, 2007; Brick and Chidambaran, 2010; Lin et al., 2014; Baccouche \& Omri, 2014). Firm leverage $L E V$ is expected to have a positive association with the board of directors' effectiveness $B D E F F$ (Greco, 2010; Baccouche \& Omri, 2014; Hahn \& Lasfer, 2016). As for the firm performance ROA, the sign is expected to be negative in relationship with board of directors' effectiveness BDEFF (Vafeas, 1999; Brick \& Chidambaran, 2010; Hahn, 2007; Baccouche \& Omri, 2014; Hahn \& Lasfer, 2016; Al-Najjar, 2012; Adams, 2005).

\section{Empirical Results and Discussions}

The descriptive statistics are illustrated in 2. These include the mean, standard deviation, minimum and maximum of each variable in the sample data set.

Table 2

Descriptive statistics

\begin{tabular}{lcccc}
\hline. & Minimum & Maximum & Mean & Std.Deviation \\
\hline BDEFF & 8 & 171 & 43 & 17.75575 \\
BDSIZE & 4 & 11 & 8 & 1.49619 \\
BDMEET & 2 & 22 & 5 & 2.15861 \\
FSIZE & 35461604 & 340041000000 & 13228896605 & 44618908643 \\
LEV & .00 & .86 & .2658 & .20476 \\
ROA & -.51 & 1.00 & .5074 & .32357 \\
\hline
\end{tabular}

Table 2 shows that differences in values exist among the variables included in the model of this study. It is shown that the range of $B D E F F$ is from 8 to 171 with an average of 43 and a standard deviation of 17.75575 . The mean of $B D S I Z E$ is 8 with a maximum of 11 and a minimum of 4 and a standard deviation of 1.49619 . The mean of BDMEET is 5 with a maximum of 22 and a minimum of 2 and a standard deviation of 2.15861. The range of FSIZE is from 35461604 to 340041000000 with an 
1254

average of 13228896605 and a standard deviation of 44618908643 . The range of $L E V$ is from .00 to .86 with an average of .2658 and a standard deviation of .20476 . The mean of $R O A$ is .5074 with a maximum of 1.00 and a minimum of -.51 and a standard deviation of .32357 .

Table 3

Description of valid and missing cases

\begin{tabular}{lccccccc}
\hline & $\mathbf{2 5 \%}$ & $\mathbf{2 1 0} \%$ & $\mathbf{1 0 \%}-\mathbf{- 2 0} \%$ & $\mathbf{2 1 \% - 3 0 \%}$ & $\mathbf{3 1 \%} \mathbf{- 4 0 \%}$ & $\mathbf{4 1 \% - 5 0 \%}$ & $\mathbf{2 5 1 \%}$ \\
\hline Number of cases & 464 & 443 & 464 & 464 & 464 & 464 \\
Missing cases & 0 & 21 & 0 & 0 & 0 & 458 \\
\hline
\end{tabular}

Table 3 and Table 4 show that the majority of major family shareholders $(31.6 \%)$ own more than $10 \%$ of the ordinary shares, and $(29.3 \%)$ own more than $5 \%$.

Table 4

Descriptive statistics of sample distribution

\begin{tabular}{|c|c|c|c|c|c|c|c|c|c|c|c|c|c|c|}
\hline & \multicolumn{2}{|c|}{$\begin{array}{l}\stackrel{0}{i n} \\
\wedge 1\end{array}$} & \multicolumn{2}{|c|}{$\frac{\stackrel{\ominus}{\theta}}{\wedge I}$} & \multicolumn{2}{|c|}{ 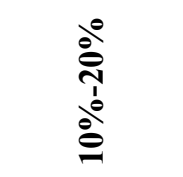 } & \multicolumn{2}{|c|}{ 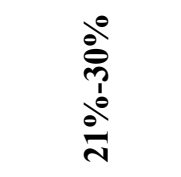 } & \multicolumn{2}{|c|}{$\begin{array}{c}\stackrel{0}{e} \\
\stackrel{\theta}{+} \\
\frac{\partial}{e}\end{array}$} & \multicolumn{2}{|c|}{ 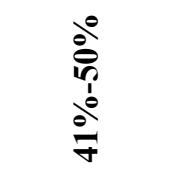 } & \multicolumn{2}{|c|}{$\frac{\partial^{0}}{\sqrt{n}}$} \\
\hline & $\begin{array}{l}\text { in } \\
\wedge 1\end{array}$ & $\begin{array}{l}\frac{D}{5} \\
\frac{0}{0} \\
\frac{ \pm}{0}\end{array}$ & $\underset{\wedge I}{\stackrel{0}{\theta}}$ & 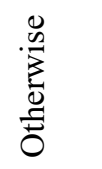 & $\begin{array}{l}\stackrel{0}{0} \\
\stackrel{0}{1} \\
\stackrel{\theta}{e} \\
\stackrel{0}{0}\end{array}$ & $\begin{array}{l}\frac{D}{5} \\
\frac{0}{0} \\
\frac{0}{0}\end{array}$ & $\begin{array}{l}\stackrel{\partial}{\theta} \\
\stackrel{\theta}{\theta} \\
\frac{\partial}{2}\end{array}$ & $\begin{array}{l}\frac{D}{5} \\
\frac{0}{0} \\
\frac{0}{0}\end{array}$ & 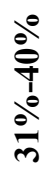 & $\begin{array}{l}\frac{D}{0} \\
\frac{0}{0} \\
0 \\
0\end{array}$ & 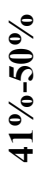 & $\begin{array}{l}\frac{D}{5} \\
\frac{0}{0} \\
\frac{ \pm}{0}\end{array}$ & $\frac{\partial^{0}}{n}$ & $\begin{array}{l}\frac{D}{5} \\
\frac{0}{0} \\
\frac{ \pm}{0}\end{array}$ \\
\hline Frequency & 136 & 328 & 140 & 303 & 46 & 418 & 10 & 454 & 3 & 461 & 4 & 460 & 8 & 450 \\
\hline$\%$ & 29.3 & 70.7 & 31.6 & 68.4 & 9.9 & 90.1 & 2.2 & 97.8 & .6 & 99.4 & .9 & 99.1 & 1.7 & 98.3 \\
\hline
\end{tabular}

Pooled Ordinary-Least Square $(O L S)$ was utilized to test the level of effect of major family shareholders on board of directors' effectiveness.

Table 5

Pooled OLS Analysis Results

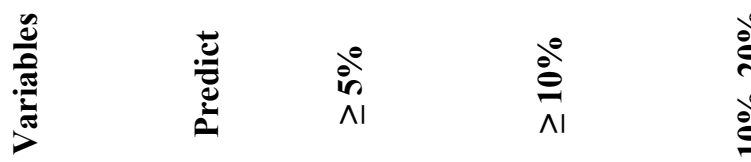

$\begin{array}{ll}\stackrel{0}{0} & \frac{\partial}{0} \\ \stackrel{0}{0} & \frac{\partial}{0}\end{array}$

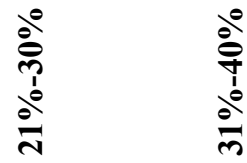

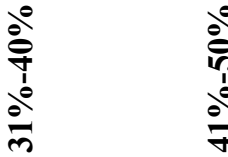

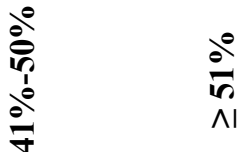

\section{Test variables}

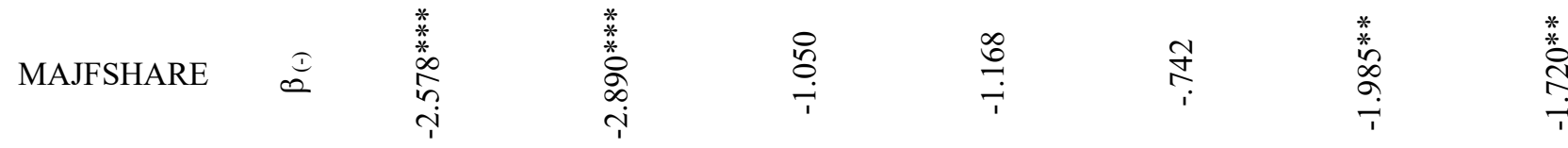

\begin{tabular}{lccccccc}
\hline $\begin{array}{l}\text { Control } \\
\text { variables }\end{array}$ & \multicolumn{1}{l}{} \\
\hline FSIZE & $4.944 * * *$ & $4.929 * * *$ & $5.219 * * *$ & $5.200 * * *$ & $5.204 * * *$ & $5.181 * * *$ & $4.732 * * *$ \\
LEV & -.799 & -.758 & -1.066 & -1.173 & -1.141 & -1.107 & -1.031 \\
ROA & $1.498^{*}$ & $1.557 *$ & 1.277 & 1.160 & 1.163 & 1.177 & 1.101 \\
$F$ & 8.919 & 9.374 & 7.443 & 7.513 & 7.296 & 8.198 & 7.679 \\
Adjusted $R^{2}$ & 6.7 & 7.0 & 5.5 & 5.6 & 5.4 & 6.1 & 5.8 \\
$P$-value & .000 & .000 & .000 & .000 & .000 & .000 & .000 \\
\hline
\end{tabular}

Bold $=$ significance at $1 \% * * *, 5 \% * *$ and $10 \% *$ (one-tailed significance)

Table 5 reports that the adjusted $R^{2 \mathrm{~s}}$ for each model, indicating that the models have explained the variance in the board of directors' effectiveness as $6.7 \%, 7 \%, 5.5 \%, 5.6 \%, 5.4 \%, 6.1 \%$ and $5.8 \%$ for the models $\geq 5 \%, \geq 10 \%, 10 \%-20 \%, 21 \%-30 \%$, $31 \%-40 \%, 41 \%-50 \%$ and $\geq 51 \%$, respectively. The $F$-values for the models are statistically significant at the $1 \%$ level, indicating 
that the overall models can be interpreted. This also gives an indication that the board of directors' model is a good fit. Table 5 displays that major family shareholders MAJFSHARE is negatively associated with the board of directors' effectiveness $B D E F F$. This result is consistent with Brunninge and Nordqvist (2004).

\section{Conclusions and Implications}

This study aims at investigating the associations of major family shareholders with board of directors' effectiveness among companies listed in Saudi Stock Exchange (Tadawul) for the periods ranging from 2012 to 2019. The final sample of this study consists of 464 firm-year observations. The results of this study depicted that major family shareholders are negatively associated with the board of directors' effectiveness. Overall, this study contributes to the body of knowledge in several ways. First, to the best of our knowledge, this study is the first to examine the classifications of several major family shareholders measures with the board of directors' composite score, namely; board size and meetings. We believe that our study provides a broad and important contribution to literature of ownership structure and board of directors' effectiveness in the context of Saudi Arabia. In addition, this study uses the agency theory framework to explain the relationship between the ownership structure and board of directors' effectiveness. In addition, the findings reported by this study could have practical implications for Saudi market, companies' management, and external auditors.

This study is subject to several limitations although it achieved its objectives. This study examined the major family shareholders in Saudi market as internal corporate governance mechanisms. Future lines of research may consider the other internal corporate governance mechanisms such as government, audit committee characteristics. In addition, the sample of this study consists of the manufactured companies. Future studies may include the other companies from banking, insurance, and telecommunication sectors. Furthermore, the dependent variable in this study is an interaction term of the board size and board meetings. Future studies may include the other board of directors' characteristics such as board independence, financial expertise and multiple directorship in the composite score of the board of directors' effectiveness. This study is conducted in the setting of Saudi Arabia. Future lines of research may replicate the model of this study in other GCC countries.

\section{References}

Adams, R. B., \& Ferreira, D. (2007). A theory of friendly boards. The journal of finance, 62(1), 217-250.

Agrawal, A., \& Knoeber, C. R. (2001). Do some outside directors play a political role?. The Journal of Law and Economics, 44(1), 179-198.

Aljaaidi, K. S., \& Hassan, W. K. (2020). Energy Industry Performance in Saudi Arabia: Empirical Evidence. International Journal of Energy Economics and Policy, 10(4), 271-277.

Aljaaidi, K. S., Bagais, O. A., \& Adow, A. H. E. (2021). The Impact of Board Activity on The Audit Committee's Effectiveness Score: Empirical Evidence from Saudi Arabia. The Journal of Asian Finance, Economics, and Business, 8(1), 179-185.

Aljaaidi, K., \& Bagais, O. (2021). The effect of company performance on audit committee diligence: The case of manufacturing companies in Saudi Arabia. Accounting, 7(2), 391-394.

Aljaaidi, K., Bagais, O., \& AlAbdullatif, S. (2021). Audit efficiency and board activity in Saudi Arabia: Empirical investigation. Accounting, 7(4), 893-898.

Aljaaidi, K., Sharma, B., \& Bagais, O. (2021). The effect of board characteristics on the audit committee meeting frequency. Accounting, 7(4).

Al-Janadi, Y., Rahman, R. A., \& Alazzani, A. (2016). Does government ownership affect corporate governance and corporate disclosure?. Managerial Auditing Journal, 31(8/9), 871-890

Al-Najjar, B. (2012) The determinants of board meetings: evidence from categorical analysis, Journal of Applied Accounting Research, 13, 178-90.

Al-Thuneibat, A.A., Al-Rehaily, A.S. and Basodan, Y.A. (2015). The impact of internal control requirements on profitability of Saudi shareholding companies. International Journal of Commerce and Management, 25(2), 196-217.

Al-Twaijry, A. A., Brierley, J. A., \& Gwilliam, D. R. (2003). The development of internal audit in Saudi Arabia: an institutional theory perspective. Critical Perspectives on Accounting, 14(5), 507-531.

Alzahrani, Y. A. (2013). The corporate governance in Saudi listed companies. International Journal of Humanities and Management Sciences (IJHMS), 1(4), 9-11.

Baccouche, S., Hadriche, M., \& Omri, A. (2014). Multiple directorships and board meeting frequency: Evidence from France. Applied Financial Economics, 24(14), 983-992.

Bagais, O., \& Aljaaidi, K. (2020). Corporate governance attributes and firm performance in Saudi Arabia. Accounting, 6(6), 923-930.

Barako, D.G., Hancock, P., \& Izan, H. (2006). Factors influencing voluntary corporate disclosure by Kenyan companies. Corporate Governance: An International Review, 14(2), 107-125.

Brick, I. E., \& Chidambaran, N. K. (2010). Board meetings, committee structure, and firm value. Journal of Corporate Finance, $16(4), 533-553$. 
Brunninge, O., \& Nordqvist, M. (2004). Ownership structure, board composition and entrepreneurship: Evidence from family firms and venture-capital-backed firms. International Journal of Entrepreneurial Behaviour \& Research, 10(1/2), 85-105.

Cai, J., Liu, Y., \& Qian, Y. (2009). Information asymmetry and corporate governance. Drexel College of Business Research Paper No. 2008-02.

Carcello, J. V., Hermanson, D. R., Neal, T. L., \& Riley Jr, R. A. (2002). Board characteristics and audit fees. Contemporary accounting research, $19(3), 365-384$.

Chahine, S. (2007). Activity-based diversification, corporate governance, and the market valuation of commercial banks in the Gulf Commercial Council. Journal of Management and Governance, 11(4), 353-382.

Chahine, S., \& Tohmé, N. S. (2009). Is CEO duality always negative? An exploration of CEO duality and ownership structure in the Arab IPO context. Corporate Governance: An International Review, 17(2), 123-141.

Coles, J. L., Daniel, N. D., \& Naveen, L. (2008). Boards: Does one size fit all?. Journal of financial economics, 87(2), 329-356.

Conger, J. A., Finegold, D., \& Lawler, E. E. (1998). Appraising boardroom performance. Harvard Business Review, 76, 136164.

Fama, E. F., \& Jensen, M. C. (1983). Separation of ownership and control. The journal of Law and Economics, 26(2), $301-325$.

Goodstein, J., Gautam, K., \& Boeker, W. (1994). The effects of board size and diversity on strategic change. Strategic Management Journal, 15(3), 241-250.

Greco, G. (2011). Determinants of board and audit committee meeting frequency. Managerial Auditing Journal, 26(3), 208-229

Guest, P. M. (2009). The impact of board size on firm performance: evidence from the UK. The European Journal of Finance, $15(4), 385-404$.

Hahn, P. D., \& Lasfer, M. (2007). Vanishing board meetings: Has governance doomed the board meeting. London: Cass Business School Research Paper.

Hahn, P. D., \& Lasfer, M. (2016). Impact of foreign directors on board meeting frequency. International Review of Financial Analysis, 46, 295-308.

Jensen, M. C. (1993). The Modern Industrial Revolution, Exit, and the Failure of Internal Control Systems. Journal of Finance $48,831-880$

Jiraporn, P., Davidson III, W. N., DaDalt, P., \& Ning, Y. (2009). Too busy to show up? An analysis of directors' absences. The Quarterly Review of Economics and Finance, 49(3), 1159-1171.

Laksmana, I. (2008). Corporate board governance and voluntary disclosure of executive compensation practices. Contemporary Accounting Research, 25(4), 1147-1182.

Lin, Y. F., Yeh, Y. M. C., \& Yang, F. M. (2014). Supervisory quality of board and firm performance: a perspective of board meeting attendance. Total Quality Management \& Business Excellence, 25(3-4), 264-279.

Lipton, M., \& Lorsch, J. W. (1992). A modest proposal for improved corporate governance. The Business Lawyer, 48(1), 5977.

O’Sullivan, M., Percy, M., \& Stewart, J. (2008). Australian evidence on corporate governance attributes and their association with forward-looking information in the annual report. Journal of Management and Governance, 12(1), 5-35.

Omran, M. M., Bolbol, A., \& Fatheldin, A. (2008). Corporate governance and firm performance in Arab equity markets: Does ownership concentration matter? International Review of Law and Economics, 28(1), 32-45.

Pearce, J. A., \& Zahra, S. A. (1992). Board composition from a strategic contingency perspective. Journal of Management Studies, 29(4), 411-438.

Raheja, C. G. (2005). Determinants of board size and composition: A theory of corporate boards. Journal of Financial and Quantitative Analysis, 40(2), 283-306.

Ramos, R., \& Olalla, M. (2011) Board characteristics and firm performance in public founder- and nonfounder-led family businesses, Journal of Family Business Strategy, 2, 220-31.

Vafeas, N. (1999). Board meeting frequency and firm performance. Journal of Financial Economics, 53(1), $113-142$.

Ward, A. J., Brown, J. A., \& Rodriguez, D. (2009). Governance bundles, firm performance, and the substitutability and complementarity of governance mechanisms. Corporate Governance: An International Review, 17(5), 646-660.

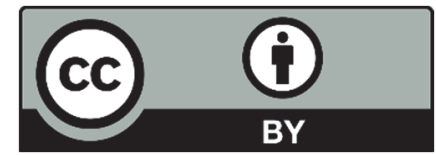

(C) 2021 by the authors; licensee Growing Science, Canada. This is an open access article distributed under the terms and conditions of the Creative Commons Attribution (CC-BY) license (http://creativecommons.org/licenses/by/4.0/). 